\title{
Stalinist Rule and Its Communication Practices
}

\section{An Overview}

\author{
LORENZ ERREN
}

In the present article, I will attempt to outline the communicative aspect of Stalin's dictatorship and pose for discussion a number of conclusions I reached while writing my dissertation (Erren 2008). Throughout the text, the concepts of "social relationship", "power", and "domination" [Herrschaft] will be based on the classical definitions of Max Weber. Following Niklas Luhmann, I will furthermore presuppose that social relationships, power, and domination can be established only by means of communication, while stressing the fact that under Stalin the latter largely took place in the context of a "public of physically present individuals".

\section{Obshchestvennost' in Social Space and Historical Context}

The Soviet Union inherited the forms of communication and media formats that emerged in the constitutional states of the nineteenth century, where, according to Habermas, they constituted a rational, discursive "liberal public sphere" [bürgerliche Öffentlichkeit]. With some delay, this development also occurred in late Tsarist Russia (Habermas 1962; Hagen 1982). The dictatorship of the Bolsheviks eliminated these early beginnings. Yet even after the October Revolution, elections, popular referenda, legal hearings, Party and trade union meetings, demonstrations, newspapers, theater performances, and scientific debates all shaped 
public life-without, however, constituting a "liberal public sphere". Why then did the Bolsheviks make such efforts to keep these forms of participation alive? The allusion to a pseudo-democratic façade is as insufficient an explanation as the suggestion that they could hardly abolish the representative bodies that had mandated the political takeover in 1917 and to which the Soviet state owed its name (Carson 1956).

My thesis holds that Stalin's political achievement consisted in his ability to create a new type of public sphere based on the inherited forms of participation. This public sphere allowed him to control, modify, and destroy social relationships and to refashion them according to his own views. Similarly to other dictators with paranoid tendencies, Stalin viewed all social relationships as potential sources of an oppositional ill will that was directed against him. The communicative structure that allowed him to avert this danger was Soviet obshchestvennost'. Throughout the present article, this concept will be used to refer to the local public sphere, organized and controlled by the respective Party authorities, in which the entire loyal Soviet population was meant to participate. The term was first widely used in the context of educational institutions and in those cases where the usual discourse of "Party work" or the "proletarian masses" seemed inappropriate. In the late 1930s, it belonged to the standard vocabulary of the central press. It was commonly prefixed with an adjective: nauchnaia obshchestvennost', for instance, would thus designate the entirety of scientists, professors, and students who were organized in a specifically Soviet manner (see, for instance, the list of references in: Demidov 1999: 253-263).

The most important element of obshchestvennost' were the notorious meetings conducted in all Soviet institutions. Before describing their modes of operation in more detail, we must determine more precisely the place of obshchestvennost' in social space and historical context. It was initially implemented only in places where the Bolsheviks had already firmly established their rule, where they were in full control of the police as well as financial and media-related means of power, and where the above-mentioned forms of participation already existed. At first, this was only the case in large cities, where the population (especially clerks, laborers, employees, and students) could be integrated into the new public sphere in a relatively quick and uncomplicated manner. There the regime could rely on the corporate and administrative apparatus, as well as on mass organizations such as Party, trade union, and Komsomol. In the provinces, villages, and non-Russian borderlands, this integration was accomplished much later and only with great effort. 
Soviet meetings and elections always played a significant role in this process (see: Alekseev 1929: 316-408; Anweiler 1958; Carson 1956; Leng 1973; Zaitseff 1925: 383-392; Bohn 2008: 524-549). They differed from Western parliaments in the absence of clear statutes and functions. Having emerged from meetings of striking soldiers and workers in 1917, they resembled a kind of "permanent national uprising" during the first years. Physical presence was of greater importance than the rules of procedure. Even after the introduction of the first Soviet constitution in 1918 the assemblies of the Soviets retained their meeting-like character (Gimpel'son 1995: 27). In the 1920s, the Bolsheviks viewed Soviet elections and assemblies as a "school" of political education (Carson 1956: 12; Kim 1965: 7). They perceived the election campaigns as a welcome means of gradually integrating the rural world and the Asian periphery into the Soviet communication space (Kuchkin 1962; Kukushkin 1968). The casting of votes did not occur in private, but by show of hands during election meetings. However, the Party also required the deputies to account for their work at these campaigns (Anonymous 1928d: 4). The propaganda organs viewed the representatives' duty to personally justify themselves to the voters as proof that Soviet elections were more democratic than the parliamentary voting system (Anaonymous 1935b; see also Zlatopolskii 1982: 240-250). In the 1930s, these public reports in turn took the character of solemn ritual events.

The right to vote became of great significance for the process of integration in yet another context. Anyone who had belonged to the "propertied classes", tsarist officialdom, or the clergy, or whom the regime mistrusted for other reasons, was deprived of his voting rights and classified as a "socially alien element". He was denied membership in the Party, the Komsomol, and trade unions, as well as the prospect of an attractive workplace or admission to a university. The population was thereby given a clear sign that the revolutionary struggle was continuing. Only those in possession of the right to vote could integrate themselves into Soviet obshchestvennost'. It was highly significant that the possession of the right to vote, of all things, became the criterion for distinguishing between loyal citizens and presumed "enemies".

The "Great Terror" of the 1930s affected different groups of people in very different ways, depending on the nature and degree of their social integration. Groups that were poorly integrated into the "Socialist public sphere" due to their "alien" class origins or other "shortcomings," which exhibited a large number of "alien elements", or belonged to certain ethnicities, were increasingly likely to become victims of so-called "mass 
actions" or ethnic cleansing. The largest mass operation was initiated

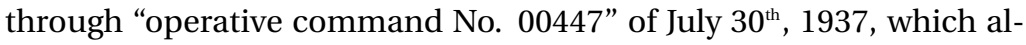
lowed for the execution and arrest of nearly 270,000 citizens. Apart from the disenfranchised, the other victims of the countless mass arrests, deportations, and executions carried out by the secret services included farmers who resisted the collectivization (the so-called kulaks), countless ethnic groups, and eventually such fringe groups as the homeless. Members of this group of victims were typically accused of an anti-Soviet attitude, but not necessarily of plotting terrorist attacks.

On the other hand, social spaces that were closer to the center, had long been integrated into obshchestvennost', and were generally not susceptible to "mass actions" (such as the state apparatus, professors, the personnel of important industrial firms and, not least, the Party elite itself) became the site of the "witch hunts" that Western scholarship has not entirely correctly defined as "purges" for some decades. Such searches explicitly focused on members of terrorist organizations who had cunningly "disguised" themselves as loyal Soviet citizens and were allegedly planning the murders of Stalin and his comrades-in-arms. The first of these campaigns of exposure was triggered in late 1934 by the fatal attack on the Leningrad Party leader Sergei Kirov. Within institutions close to Party and state, the smoothness of procedures was ensured not only by police and military means, such as registration cards, prisons, freight trains, and barbed wire, but also through the mechanisms of obshchestvennost'. All loyal Soviet subjects were obligated to participate in the "exposing" of "enemies, infiltrators, saboteurs, conspirators, and terrorists in disguise" by denouncing colleagues and superiors, or at least retrospectively approving of their arrest. According to the current state of knowledge, it is difficult to determine to what extent the outcome of Soviet meetings influenced the NKVD in its choice of victims. Here it suffices to point out that obshchestvennost' supplied the state security services with insider knowledge and social support.

Both approaches, discretely executed mass actions and the public "exposure of the enemy" alike, were directed less against the affected individuals than against the milieus and relationship networks which the regime considered potentially conducive to political opposition. In order to better survey these social landscapes, the regime carried out large-scale eliminations [Flurbereinigungen].

Even though obshchestvennost' only rarely became an arena for paranoid hunts of harmful subjects after 1938, its significance continued to increase. Until the period of Perestroika, it remained the most effective 
instrument for the complete domination of society. It guaranteed that the regime would only have to resort to physical force in rare cases. It supported Party functionaries, factory directors, and department chairmen alike in disciplining individual members of staff. At the same time, obshchestvennost' allowed the regime to control whether and how successfully these officials carried out their own executive functions.

\section{The Public Assembly (Versammlungsöffentlichkeit)}

Soviet obshchestvennost' constituted itself by means of the assembly. All governmental and societal institutions, from the Komsomol group and the city council to the helm of the Party, regularly conducted meetings. Together with other forms of communication, such as wall newspapers, company bulletins, local daily news, demonstrations, and collective sponsorships, obshchestvennost' formed a large continuum: staff meetings were covered in newspaper articles, whose content could in turn become the topic of the next meeting. Categories of public law were largely irrelevant to this process. Questions of ordinance, jurisdiction, eligibility, and correct procedure were rarely deemed worthy of consideration.

From a formal perspective, many of these meetings corresponded to the types of committees that are found in liberal constitutional states as well. And yet their purpose was different. Whereas public authorities and enterprises in liberal societies expect their committees to ensure the competent, smooth, and above all discreet solution of any problems, Stalinist obshchestvennost' was primarily an institution of the political public sphere. Here, grievances were to be addressed vocally and conflicts to be resolved publicly. It was characteristic of the Stalinist assembly to outgrow its original function and sphere of competence, and to permit itself to comment on issues of world politics such as the Spanish Civil War. All the more so, it was concerned with problems that were actually relevant to a certain environment. In terms of its structure, these events were rather flexible and could easily be enriched with other forms of communication. Depending on the occasion, the assembly could assume the character of a parliamentary debate, a court hearing, a memorial service, an exam, or a school lesson.

The direction of obshchestvennost' was essentially incumbent upon the official functionaries of each Party cell. Apart from the cell itself, which consisted of members and candidates, they attended to a network 
of other organizations, such as trade unions, the Komsomol, the "village poor", as well as occasional initiative groups, whose members were invited to participate in "open Party meetings". These officials' reports to the higher authorities show that they understood themselves as organizers who were required to "incorporate" as many eligible people as possible into political life and who were pleased whenever they could report active participation in a high number of events. Occasionally, the quality of Party work in cells at the local level was comprehensively evaluated. A key concept of Party activism was "attentiveness". This meant that good Party secretaries-in contrast to "ossified bureaucrats"—-did not simply study files, but were expected to dedicate themselves to the people as well. In practice, officials attempted to fulfill this demand by coercing citizens in their sphere of responsibility to participate in assemblies, or even to become members in a Soviet organization.

Since hardly anyone could evade this pressure of integration in the long run, scholars and historians of the Soviet Union have frequently described the practice of meetings as an "artificial staging" or a "meaningless ritual". In my view, however, the term "performative" (or "performance") is more adequate. It similarly refers to the dramatics and theatricality of the spectacle, but without prematurely characterizing the latter as "artificial" or "inauthentic". The term originates in linguistics. In the context of speech act theory, it designates statements that simultaneously describe and carry out an action, such as binding agreements, for instance. Even if it occurs in a disingenuous or coerced manner, the validity of the act is not necessarily compromised. Stalinist assemblies consisted of a succession of such performative acts. They served as the stage on which subjects had to "speak Bolshevik" or "act Soviet", i.e. to articulate an individual standpoint in politically correct language. Everyone realized that the request to speak (whether it was meant "sincerely" or not) could have serious consequences for oneself and others, and that one could be called upon to justify statements to both the authorities and one's environment. Actors and audience were identical; uninvolved spectators did not exist. On occasion, the plot was highly dramatic, but never fictional. The assembly was the space where the grand social drama was demonstrated and made comprehensible on a small scale, and where abstract concepts of propaganda were filled with concrete meaning.

The public assembly ensured that the Soviet authorities would not carry out their sometimes delicate assignments as "mechanical, soulless apparatuses", but as vital corporations held together by ties of personal 
obligation. At the same time, it served as an instrument of qualitative "demoscopy". It did not conduct opinion polls and was incapable of supplying the authorities with exact statistical data. However, the assemblies provided them with enough opportunities for taking their subjects to task, provoking and pitting them against one another, and for attentively reading their faces in the process.

\section{Political Loyalty}

The most important task of the assemblies remained avoiding the emergence of opposition and providing the regime with social support. Earlier and more consistently than Carl Schmitt, the Bolsheviks understood politics of any kind as the differentiation between friend and enemy. Not only their political language, but the structure of their newly created public sphere as well was designed with the goal of continually reproducing this contrast. Whoever integrated himself into obshchestvennost' knew that he was thereby entering the "halls of glory" and exposing himself to a permanent compulsion to confess. Demonstrations, commemorative events, voluntary subbotnik shifts, or membership in Party-affiliated organizations (Komsomol, OSOAVIAKhIM, the Union of House Wives, and others) all represented relatively convenient opportunities to demonstrate one's political loyalty. However, Soviet propaganda demanded support "not only in word, but in deed as well". This could encompass participation in "Socialist competition" and the "voluntary" subscription to government bonds, but also personal commitment to the enforcement of political measures such as collectivization. In the end, "deeds" referred to performative acts in the above-mentioned sense of speech act theory. Just as in democratic parliaments, the rule of the majority applied during political votes in the Soviet assemblies - with the fundamental difference, however, that the minority no longer enjoyed immunity. The transition of the Party from an unprejudiced culture of discussions and elections to a "monolithic" closeness was completed in the course of the 1920s. At that time, the Stalinist majority first illegalized the Trotskyite minority through the prohibition of fractions and then outvoted, expelled, and finally arrested its members. Nearly all Party members who had voted for the opposition even a single time after 1922 were later shot (Daniels 1962). This approach was of paradigmatic significance not only for the Party, but for all of obshchestvennost'. Those who did not wish to 
become "Trotskyist" martyrs had to agree with the majority vote during political elections, which therefore almost always ended unanimously.

Stalin was virtually obsessed with all procedures that resulted in the political taking of sides, the formation of camps, and decisive votes. It is difficult to determine whether he actually believed that Lenin's former comrades-in-arms were "enemy conspirators" who intended to assassinate him. It is clear, however, that he demanded proofs of loyalty from his followers and subjects that hardly fell short of those of the Old Testament God. Under Stalin, the political vote was not a civil decisionmaking process, but a matter of life and death. It symbolized not the fight between Stalin and his opponents, but was part of this struggle. It is therefore no coincidence that the politburo initiated the terrorist "mass actions" at the same time as the constitution overturned the voting rights restrictions that had been valid until then. One enabled the other: the "enemies" were no longer prevented from forming independent political will by legal, but by terrorist means.

Even the admissions of guilt which were demanded of Trotskyites and "right-wing dissenters" were essentially nothing else than the belated retraction of a "false" vote. But their hopes of using such retractions to reintegrate themselves into the Party would be satisfied only temporarily. In the long run, their increasingly submissive expressions of remorse did nothing but allow the propaganda to portray them as "twofaced hypocrites". Stalin's paranoid obsession with the notion that each drastic measure and every true advance would inevitably generate "hostile" resistance and require violent reassertion, was enacted a thousand times over in the assemblies. Where opposition failed to manifest itself, the leaders of obshchestvennost' knew enough ways to incite dispute through unpopular suggestions and to antagonize their audience until someone was finally provoked to an expression of disagreement. The individual could then promptly be declared an "enemy" and "defeated" in an exemplary manner. The same regime which at other times indifferently accepted the death of thousands, ascribed to each individual, however insignificant or weak, a grotesquely exaggerated importance during political elections. Whoever actually or allegedly took the side of the "enemy" during a vote would immediately attract the attention of high-ranking Party authorities. Even school children who had made ambiguous statements were occasionally forced to formally confess their guilt, to distance themselves from their actions, and to vow selfimprovement (see examples in: Erren 2008: 234-235).

Skilled Party activists were intent on finding morally trustworthy wit- 
nesses for the prosecution. Authority figures were to be attacked not by just anyone, but by individuals whose statements carried weight, i.e. by their previously closest co-workers, their favorite students, their best friends, and their spouse. This was to occur not anonymously, but "before the eyes of the whole world". Such an arrangement had the piquant side effect of morally discrediting entire groups of people even on the basis of traditional norms; they thereby lost their ability to convincingly represent oppositional viewpoints. The fact that Party members not only approved the arrests of millions of people during the notorious assemblies, but generally accepted these arrests with almost no objections, speaks to the skillfulness of Stalin's methods.

Scholarship often expresses the notion that such meetings primarily aimed at establishing a "truth" about the persons involved. This is only true in a very specific sense. The very structure of the assembly made it unsuitable for conducting insightful biographical or psychological research. In my view, the interest in the personal history of individuals was largely a pretext; it was of greater importance to determine how someone would act in the future. The "personal truth" in question was not elicited, but produced in this process: the individual turned into the "Stalinist subject" in the context of a conflict of loyalties, during which the individual had to decide between the interests of the regime and his fellow man, between career opportunities and one's moral integrity. From that point on, the "truth" about any individual was firmly established by each of his decisions (for a similar account, see: Kharakhordin 1999: 164-175). The later dissident movement arose from the desire to morally resist this type of corruption.

\section{Between Ritualization and Escalation Obshchestvennost' in Everyday Life}

The history of the public assembly in Russia consistently reflects the traditionally complicated relationship between the center of power and local government authorities (see in details: Rosenfeldt 1990; Rees 2002). Local leaders usually made efforts to suppress or control public communication in their own sphere of responsibility. In order to accurately assess the psychological effect of the above-described assemblies, one must consider that strict authoritarian measures were generally taken for granted in Russo-Soviet administrative and labor relations, and that public criticism of superiors amounted to the flagrant violation of a 
taboo. During the NEP years, even Communist Party secretaries, Soviet state officials, and "red" directors were inclined to believe that public disputes could only harm their institutions. While they could not simply abolish the institutions of obshchestvennost' which had been introduced during the Revolution, they were generally powerful enough to keep them under control. If anywhere, this proved difficult in the factories of the capital. The workforce there was accustomed to the representation of their interests through trade union. As a result, the postulate of "workers' power" was occasionally interpreted to mean that foremen and other superiors in "bourgeois" attire were no longer in a position to give them orders. Sergei Iarov has described how even in these places the authorities were able to subdue workers with a paternalistic carrot-and-stick strategy. The regime increasingly reacted to strikes with lockouts and arrests, while local management disciplined their personnel with wage differentiation and the threat of dismissal. In doing so, factory managers could firmly count on the support of Party and trade union officials, who gave priority to the increase of production. If union officials paid any attention to the interests of workers at all, they were concerned with the quick and discreet resolution of conflicts. The workers soon realized that supplicating led to greater results than striking. During wage disputes they continued to defend their position in "heated debates" with the management, but always unanimously accepted their resolutions at the end of a meeting (Iarov 2006: 500-501; Ul'ianova 2001: 155).

During the NEP years, company meetings were held only rarely and not regarded very seriously. Factory supervisors preferred not to make an appearance at all, but the workers, too, were prudent enough to refrain from participating (Schattenberg 2002: 103; Schröder 1988: 116). Wall newspapers were in effect subject to pre-censorship.

No one was outraged in the least that officials were distributing elected offices at their own discretion and thereby confidently defying all conceivable organizational guidelines. No one except Stalin. When he initiated the "Great Turn" in 1928, he accused local officials of having, among other things, disregarded procedural regulations and thereby the dictates of "managerial", "trade-union" and "Party-internal democracy". The propaganda of the time alleged that "bourgeois" and "right-wing opportunist" officials deliberately mistreated workers in order to foment anti-Soviet sentiment. In order to put an end to activities of this kind, the new regulations demanded that every proletarian be given the opportunity to use his voting rights and to "express criticism" in wall newspapers and assemblies at any time, without any risk, and in an uncensored 
manner. Thereafter, Soviet institutions were required to provide evidence proving that they "practiced democracy" according to the rules. In some places, charts were used to document how often each factory conducted meetings and how many workers had vocally participated in them (Ingulov 1928: 44-45). Party and trade union officials who had been summarily appointed were subsequently required to formally run for public office.

The authorities in charge searched for ways to comply with these demands while simultaneously avoiding escalation. They required workers to discuss critical contributions with the company or union management prior to the beginning of an assembly (see: Anonymous 1928e: 1.7). It was generally considered necessary to first instruct workers on how to appropriately present any justified criticisms politely and in the proper form. Criticism should not be broad, but instead always address concrete grievances (see: Anonymous 1928c). Some institutions introduced the rule that only the lower authorities, up to the raion committee, could be criticized, while those superior to it were off limits (Ingulov 1928: 29-40).

The central press mocked such efforts, while simultaneously sending an equivocal message. On the one hand, it argued, "criticism from below" could only make professional life more transparent and thereby more efficient. On the other hand, the press also expressed hope that workers' criticism would expose numerous "bourgeois opportunists" or even "saboteurs" among leading members of the personnel. Yet it was not so easy to break the workers' reserve in 1929. They often responded to calls for criticism by requesting guarantees of immunity (Alikhanov 1928: 119). Eventually, the propaganda organs made it quite clear that they were intent on provoking scandal as such. The latter arose as soon as important Party authorities decided to participate in the organization of “workers' criticism” themselves. They did so, for instance, by guaranteeing their support to controlling organizations such as the "Workers' and Farmers' Inspection" or the "light cavalry". While public criticism was supposed to remain "objective" and "constructive", it often devolved into a spectacle of exposure in practice. The head of the Workers' and Farmer's Inspection, Stalin's friend Ordzhonikidze, for instance, spoke enthusiastically about a group of Komsomoltsy who had "inspected" an institution and subsequently published portraits of employees who, in their view, worked "too bureaucratically" (Izvestiia, December $21^{\text {st }}, 1928$, 2-3).

Stalin expected his Party functionaries to be prepared to demonstrate 
the meaning of the current Party line to the organs of obshchestvennost' under their supervision, by means of punishments that were skillfully designed to set examples. The regime was far from satisfied when in 1929 the Ukrainian Federation of Labor Unions dissolved numerous local committees that had been improperly elected. While it was pleased with the result, it disapproved of the way it had been achieved. In its view, the Federation first should have summoned large assemblies, encouraged workers to express criticism, and relieved the officials of their offices only afterwards and before a large audience (Izvestiia, December $6^{\text {th }}, 1928,3$ ).

Because Stalin believed that the atmosphere in both administrative agencies and factories was generally far too harmonious (the propaganda organs would lament the "lack of self-criticism" and "vigilance"), he repeatedly ordered comprehensive "purges" (chistki, proverki) to be carried out. These were effective not because of the expulsion (or even arrest) of large groups of people, but due to the embarrassing manner of their implementation. A chistka meant that all issues pertaining to the personnel were to be publically discussed. Every employee or Party member was required to account before the collective for his social origin, political biography, professional qualifications, behavior at the workplace, as well as for his private life. The lively participation of the public was expressly desired, especially whenever the goal was to expose and punish "careerist and over-bureaucratized elements". In 1937, similar motives prompted the regime to conduct re-elections in both the Party and the Soviets. For once, voters were actually to be given the opportunity of publically criticizing officials and even voting them out of office. The press spitefully reported about meetings in which anyone was convicted of misrepresenting one's past or of abusing one's position of power.

During the 1930s, the willingness of employees to become involved in the processes of obshchestvennost' gradually increased. In the industrial sphere, it reached its peak in connection with the Stakhanovite movement, which was, after all, created for precisely this purpose. Dietmar Neutatz has impressively demonstrated how the regime managed to install a new, more effective model of dutifulness within the framework of obshchestvennost' on the construction site of the Moscow Metro (Neutatz 2001). Instead of silently obeying their superiors, enthusiastic young Communists explicitly expressed their agreement with the goals of state, Party, and company management. However, they also gave proof of their loyalty by complaining about the misconduct of superiors, by independently calling into question work procedures, by addressing delicate 
issues and thereby also risking conflict. They unabashedly used public posters to ridicule colleagues as "idlers" and "deficit workers". "Within brigades, groups, and shifts, the meetings or councils on productivity established a public sphere, which the Communists and Komsomoltsy utilized to affirm their decisions against the majority and to silence their opponents" (Neutatz 2001: 459). However, a psychological need for dramatization became evident not only in the explicit search for "saboteurs", "spies" and "enemies", but even in cases where the only goal was to increase productivity. Occasionally, workers would stage "Socialist competitions" in the form of sports events, at which the participants were urged on by their colleagues. The assemblies were also used to celebrate the outstanding achievements of individual brigades and to propagate their formulas for success (Neutatz 2001: 350-352).

Even engineers seem to have adopted a "dramatic" attitude toward their work under Stalin's rule. They no longer saw their primary task in the organization of an always smooth and safe working process, but in risky experiments and the heroic mastery of unforeseen dangers and difficulties (see: Schattenberg 2002: 420-421).

It should be noted, however, that while company-internal hierarchies were unsettled by "purges", "Socialist competitions" and "record chases", they always retained their paternalistic character. Dramatic moments of hysteria and chaos were in turn followed by longer periods of stability. As soon as a new management group had firmly established itself, meetings would once again be conducted less commonly and in a far less scandalous manner. The organization of elections, the holding of competitions, the submission of useful criticism from below in the form of suggestions for improvement could all continue to occur, but under the guidance and direction of the responsible bosses. These leaders attempted to neutralize obshchestvennost' by means of ritualization.

As a consequence, factory collectives might occasionally send the "wise leader Stalin" a ceremonial speech that was composed in the Stalin palace of culture of the Stalin factory, located at the Stalin Square in the city of Stalinsk (Rolf 2007: 225-242).

The addressee himself had a rather ambivalent attitude toward such developments. Where unanimity had replaced all conflict, obshchestvennost' lost both its "connection with the masses" and its ability to establish legitimacy. Precisely this occurred during the long "stagnation" in the post-war decades. Even Stalin's successors failed to break the cycle of ritualization and renewed escalation. Mikhail Gorbachev's attempt to 
revive obshchestvennost' through nonviolent democratization ultimately led to its disintegration.

\section{Obshchestvennost' as an Educational Institution}

The gradual integration of the populace into obshchestvennost' also resulted in the universal pedagogization of public life. In the 1930s, at a time when workers were desperately needed everywhere and employees could hardly buy anything with bank notes alone, the mechanisms of the labor market had lost much of their disciplining effect. In this phase, the authorities learned how to utilize "Socialist competition", comrades' courts and public discussions about individual job performances as a means of leverage. Union officials spoke enthusiastically about the cathartic effect of public humiliation. Workers who had committed small thefts and remained unmoved by reprimands from their superiors reportedly burst into tears when taken to task by their colleagues. At such times, obshchestvennost' became the stage for touching scenes of repentance and exoneration, of the type contemporaries knew from the popular courtroom drama, which was widely popular at the time.

Stalin himself did not seem to have exceedingly high expectations for the methods of Socialist collective pedagogy that aimed at the wrongdoer's re-integration. In any case, he enacted Draconian laws that mandated years of imprisonment for even the slightest tardiness or petty theft.

Nevertheless, a general tendency to solve conflicts and challenges through pedagogical rather than political means became apparent even prior to Stalin's death. Ministers, school children, and writers all had to anticipate the possibility of being confronted with their sins and mistakes before a public of their peers. In such cases, it was wisest to apologize, vow improvement, and to appear generally ingenuous, unsuspecting, and submissive.

On the whole, however, the Stalinist dictatorship of education should not be understood as the project of creating a "new man" in the sense of revolutionary utopias. Central elements of these utopias-such as the need to overcome national identity, the abolishment of the family or abstinence from alcohol-were soon forgotten under Stalin's rule. One can even argue that the concept of education effective in everyday life under Stalin was merely a byproduct of the failed attempt to condition society by threat of violence. Only once the regime realized that not all 
problems disappeared with the elimination of "alien elements", did it remember that its subjects-including school children-could also be regarded as objects of education.

According to Kaganovich, one should "not beat to death" the guilty, but "thrash" them only until they bettered themselves. His statement was meant reassuringly (Izvestiia, November $1^{\text {st }}, 1929$ ). Anyone who had not been declared an "enemy" was considered susceptible to education in this sense. "Education" encompassed all measures which the authorities took with regard to the people suited for education. Under Stalin, "education" was little more than a euphemistic circumscription of the overall treatment of people that were regarded as loyal. This concept of education was entirely redundant. In practice, education preferred to use methods that are generally attributed to "poisonous" or "black pedagogy" today (Rutschky 1997). In the process, brutal methods of deterrence continued to coexist with penitent rituals of humiliation. Nevertheless, the "educational principle" rapidly gained popularity among the subjects of the regime, since it gave anyone who had been reprimanded an opportunity to "get off lightly": the more a Soviet citizen seemed to be in need of education, the less the authorities tended to ascribe his misconduct to political motives or "ill will".

After much effort, the regime and its subjects found a common "Bolshevik" language on this wavelength. Stalin accepted the role of the "head of the household" and of the "benevolent father and teacher", while the citizens acted out the role of harmless children. The legitimating model of the new system of communication was thus represented not by the enlightened, rational, and Communist Produktionskollektiv of emancipated "new men", but by the patriarchal extended family.

\section{Conclusion}

Soviet obshchestvennost' was a form of communication among physically present individuals. In this, it most closely resembles the traditional village community or the pre-modern urban public sphere. The latter presupposed the physical presence or at least the quick accessibility of its participants. It thereby differed fundamentally from the mass media public sphere of liberal democracy, which is based on methods of distancing, de-personalization, and immunization such as newspapers, ballot boxes, and free parliamentary representation. While modern mass media existed in the Soviet Union as well, they did not produce 
any distance: in order to become effective, the meaning of their message first had to be discussed, explained, and realized in the participatory public sphere of obshchestvennost'. Mandatory meetings-rather than the newspaper, radio ether, or the regulars' table at the local bar-were the decisive sounding board for political action. In the Soviet Union, important conflicts were resolved in social spaces that typically aspired towards discretion and harmony within the context of bourgeois life. In these spaces, where everything depended on binding positions rather than non-committal and anonymously collectable opinions, the regime consolidated its social base of support. Those in attendance could be forced to take sides in person. In this manner the regime succeeded in distributing the responsibility for political crimes over an alarmingly large number of people.

Stalin's regime constantly felt itself dependent on the credibility and authority of its supporters, and thus on a resource it was unable to produce by its own powers. In the last twenty years, scholarship has increasingly focused on the fate of the individual and on whether one should speak of "atomized individuals", enthusiastic "illiberal subjects", or "cynical accomplices". It is not necessary to find a conclusive answer to this question in order to comprehend Stalinism as a totalitarian system. It suffices to note, for one, that the regime positioned itself so skillfully that it was able to garner the support of believers and cynics alike. It is nowadays generally established that Stalin himself initiated and directed the Great Terror, and that it was not the consequence of any blind "radicalization from below". However, the fact that reputable Western historians could temporarily reach the opposite conclusion speaks to the alarming effectiveness of Stalin's "publicity work" and to the regime's ability to corrupt and sway individuals (see: Getty 1993; Getty 1985; Rittersporn 1991; Thurston 1996). Furthermore, Stalin was less intent on affecting the individuals themselves than the relationships, ties, and loyalties existing among them. In his view, individual persons could be manipulated and exchanged, and were thus only of limited interest-he thought in terms of political processes, scenarios, and situations instead. A number of prominent personalities, such as Solomon Mikhoels and Osip Mandel'shtam, were eliminated simply because they "disturbed the picture" at the wrong time.

In 1926, René Fülöp-Miller characterized the "theatricalization of life" as an extremely effective means of political manipulation; the mandatory Soviet assemblies provided the stage for this "theatricalization". As the executive producer of obshchestvennost', Stalin constantly chose from 
a variety of genres in order to project alternating images of triumph and disgrace. To study the biographies of his victims one must realize that their fate often depended merely on which scenario he meant to be staged at a given time. Confessions of guilt and repentance could at times be appropriate for exposing the enemy in all his "hypocritical pitifulness". On other occasions, they allowed the ruler to present himself as a benevolent, empathetic educator who had once again chosen to temper justice with mercy.

Stalinist obshchestvennost' was without any doubt a panoptic mechanism of power. It was arranged in such a way that its participants were forced to monitor one another. Nevertheless, it did not have the same effect as the sophisticated disciplinary techniques Michel Foucault described in Discipline and Punish (Foucault 1994: 267, 278). In contrast to them, obshchestvennost' never guaranteed the "efficient, discrete, and sustained improvement of performance in individuals as well as all societal 'apparatuses"'. The Stalinist participatory public sphere was not an instrument designed to implement a modern, rational-economical concept of performance. Instead, it provided the arena and the cast which allowed Stalin to stage the archaic melodrama of his politics.

\section{References}

Alekseev, N. 1929. Die Entwicklung des russischen Staates in den Jahren 1923-1929. In Jahrbuch des öffentlichen Rechts der Gegenwart 14: 316-408.

Alexopolous, G. 2003. Stalin's outcasts. Aliens, Citizens and the Soviet State 1926-1936. Ithaca: Cornell University Press.

Alikhanov, G. 1928. Samokritika i vnutripartiinaia demokratiia. Leningrad.

Anonymous. 1925. Voronezh District Center for Historical Documentation [Tsentr dokumentatsii noveishei istorii Voronezhskoi oblasti, TsDNI VO]: fond 10, opis 1, delo 166.

Anonymous. 1928a. Informatsii, dokladnye zapiski Gubkoma VKP(b), v TsK VKP(b), Ukomov, Raikomov partii ob izuchenii i obsuzhdenii reshenii XV s'ezda partii 16. 1.-15. 3. 1928. Voronezh District Center for Historical Documentation [TsDNI VO]: fond 1, opis 1, delo 2093. Anonymous. 1928b. Materialy obsledovaniia-dokladnye zapiski, protokoly po voprosu vypolnenii direktiv partii o vnutripartiinoi demokratii, kritike i samokritike v 1928 g. Voronezh District Center for 
Historical Documentation [Tsentr dokumentatsii noveishei istorii

Voronezhskoi oblasti,(hereafter referred to as TsDNI VO)]: fond 9,

opis 1 , delo 17 .

Anonymous. 1928c. O lozunge samokritiki. Bol'shevik 10: 3-7.

Anonymous. 1928d. Organizatsiia otchetnoi kampanii. Izvestiia TsK VKP

30 (October 11): 4.

Anonymous. 1928e. Voronezh District Party Committee. 1928. Report on the propagation of self-criticism from July 7. Voronezh District Center for Historical Documentation [TsDNI VO]: fond 2, opis 1, delo 136.

Anonymous. 1929. O predvaritel'nykh itogakh proverki i chistki riadov VKP(b), priniato 2.10.1929 g. TsDNI VO, fond 9, opis 1, delo 69.

Anonymous. 1934. Bor'ba za trudovuju disciplinu i rabota prizvodstvennotovarishceskikh sudov. State Archive of Russian Federation (GARF), fond 5451, opis 18, delo 232, list 65-71.

Anonymous. 1935a. Pervichnaiia partiinaia organizatsiia gazety "Kommuna”. Kharakteristiki. 1935g. Voronezh District Center for Historical Documentation [TsDNI VO]: fond 241, opis 1, delo 70.

Anonymous. 1935b. Vybory $v$ Sovety $v$ Soiuze SSR 1934-1935 g. Moscow. Anonymous. 1938. Istoriia VCP(b). Kratkii kurs. Moscow.

Anonymous. 1993 [1937]. Materialy fevral'sko-martovskogo plenuma TsK VKP(b) 1937 goda. 26 fevralia 1937 goda. Vechernee zasedanie. Voprosy Istorii 5: 3-23.

Anonymous. 1999. Zaiavlenie sekretaria SSR V. P. Stavskogo narkomu vnutrennikh del SSSR N. I. Ezhovu o poete O. E. Mandel'shtame. In Vlast' $i$ khudozhestvennaia intelligentsiia. Dokumenty 1917-1953 gg., 411-412. Moscow

Anweiler, O. 1958. Die Rätebewegung 1905-1921. Leiden: Brill.

Austin, J. 1981. Zur Theorie der Sprechakte (How to do things with words). Stuttgart: Reclam.

Baberowski, J. 2003a. Der Feind ist überall. Stalinismus im Kaukasus. Munich: DVA.

Baberowski, J. 2003b. Der rote Terror. Die Geschichte des Stalinismus. Munich: DVA.

Baberowski, J. 2006. Ordnung durch Terror. Gewaltexzesse und Vernichtung im nationalsozialistischen und im stalinistischen Imperium. Bonn: Dietz.

Binner, R. (editor). 2009a. Massenmord und Lagerhaft. Die Andere Geschichte des Grossen Terrors. Berlin: Akademie Verlag.

Binner, R. (editor). 2009b. Stalinismus in der sowjetischen Provinz 1937- 
38. Die Massenaktion aufgrund des operativen Befehls Nr. 00447. Berlin: Akademie Verlag.

Bohn, T. 2008. "Im allgemeinen Meer der Stimmen soll auch meine Stimme erklingen..." Die Wahlen zum Obersten Sowjet der UdSSR von 1958. Loyalität und Dissens im Kommunismus. Geschichte und Gesellschaft 34: 524-549.

Canetti, E. 1990. Masse und Macht. Frankfurt am Main: Fischer.

Carson, G. 1956. Electoral practices in the U.S.S.R. London: Atlantic Press.

Cassiday, J. 2000. The enemy on trial. Early Soviet courts on stage and screens. DeKalb: Northern Illinois University.

Churakov, D. 2004. Revoliutsiia, gosudarstvo, rabochii protest. Formy, dinamika i priroda massovykh vystuplenii rabochikh $v$ sovetskoi Rossii. 1917-1918 gody. Moscow.

Daniels, R. 1962. Das Gewissen der Revolution. Kommunistische Opposition in Sowjetrussland. Cologne: Kiepenheuer \& Witsch.

Danilov, V. (editor). 1999-2004. Tragediia sovetskoi derevni. Kollektivizatsiia $i$ raskulachivanie. Dokumenty $i$ materialy $v 5$ tomakh, 1927-1939. Moscow.

Demidov, S. 1999. Delo akademika Nikolaia Nikolaevicha Luzina. St. Petersburg: RKHGI.

Dönninghaus, V. 2009. Minderheiten in Bedrängnis. Sowjetische Politik gegenüber Deutschen, Polen und anderen Diaspora-Nationalitäten 1917-1938. Munich: Oldenbourg.

Erren, L. 2004. Review of Halfin, I. Terror in my soul. Communist autobiographies on trial. H-Soz-u-Kult (published April 27 ${ }^{\text {th }}$ ): http: //hsozkult.geschichte.hu-berlin.de/rezensionen/2004-2-064.

Erren, L. 2008. "Selbstkritik" und Schuldbekenntnis. Kommunikation und Herrschaft unter Stalin. Munich: Oldenbourg.

Filtzer, D. 1986. Soviet Workers and Stalinist Industrialization. The Formation of Modern Soviet Production Relations 1928-1941. London: Pluto Press.

Fitzpatrick, S. 1993. How the Mice Buried the Cat. Scenes from the Great Purges of 1937 in the Russian provinces. The Russian Review 52 (July): 299-320.

Foucault, M. 1994. Überwachen und Strafen. Die Geburt des Gefängnisses. Frankfurt am Main: Suhrkamp.

Fülöp-Miller, R. 1926. Geist und Gesicht des Bolschewismus. Darstellung und Kritik des kulturellen Lebens in Sowjet-Russland. Zurich: Amalthea. 
Getty, J. 1985. The Origins of the Great Purges. The Soviet Communist Party Reconsidered 1933-1938. Cambridge: Cambridge University Press.

Getty, J. 1991. State and Society under Stalin. Constitutions and Elections in the 1930s. Slavic Review 50 (1): 18-35.

Getty, J. and R. Manning (editors). 1993. Stalinist Terror. New perspectives. Cambridge: Cambridge University Press.

Getty, J. 1999. The Road to Terror. Stalin and the Self-Destruction of the Bolsheviks 1932-1939. New Haven: Yale University Press.

Gimpel'son, E. 1995. Formirovanie sovetskoi politicheskoi sistemy 19171923 gg. Moscow.

Gogolevskii, A. 2005. Revoliutsiia i psikhologiia. Politicheskie nastroeniia rabochikh Petrograda $v$ usloviiakh bol'shevistskoi monopolii na vlast'. St. Petersburg.

Griesse, M. 2008a. Dynamiques et contraintes de la critique à l'époque stalinienne. Traces des pratiques communicatives dans le journal d'A.G. Man'kov. Cahiers du Monde Russe et Soviétique 49 (4): 605628.

Griesse, M. 2008b. Soviet Subjectivities. Discourse, Self-Criticism, Imposture. Kritika. Explorations in Russian and Eurasian History 9: 609-24.

Grüner, F. 2008. Patrioten und Kosmopoliten. Juden im Sowjetstaat 19411953. Cologne: Böhlau.

Habermas, J. 1962. Strukturwandel der Öffentlichkeit. Untersuchungen zu einer Kategorie der bürgerlichen Gesellschaft. Neuwied: Luchterhand.

Hagen, M. 1982. Die Entfaltung der politischen Öffentlichkeit in Russland 1906-1914. Wiesbaden: Steiner.

Halfin, I. 2001. Looking into the Oppositionists' Soul. Inquisition Communist Style. The Russian Review 60: 316-339.

Halfin, I. 2003. Terror in my soul. Communist autobiographies on trial. Cambridge: Harvard University Press.

Hedeler, V. 2003. Chronik der Moskauer Schauprozesse 1936, 1937 und 1938. Planung, Inszenierung und Wirkung. Berlin: Akademie Verlag.

Hellbeck, J. 2006. Revolution in my Mind. Writing a Diary under Stalin. Cambridge: Harvard University Press.

Holenstein, A. 1991. Die Huldigung der Untertanen. Rechtskultur und Herrschaftsordnung (800-1800). Stuttgart: Gustav Fischer. 
Iarov, S. 1999. Proletarii kak politik. Politicheskaia psikhologiia rabochikh Petrograda v 1917-1923 gg. St. Petersburg

Iarov, S. 2006. Konformizm v sovetskoi Rossii. Petrograd 1917-1920-kh godov. St. Petersburg.

Ingulov, S. 1928. Samokritika i praktika ee provedeniia. Moscow.

Kharkhordin, O. 1999. The Collective and the Individual in Russia. A Study of Practices. Berkeley: University of California Press.

Khlevniuk, O. 1993. Stalin i Ordzhonikidze. Konflikty v Politbiuro v 30-e gody. Moscow.

Kim, A. 1965. Sovetskoe izbiratel'noe pravo. Voprosy teorii, izbiratel'nogo zakonodatel'stva i praktiki ego primeneniia. Moscow.

Kiselev, A., editor. 1996. Khrestomatiia po otechestvennoi istorii (19141945 gg.). Moscow.

Kodin, E. 1995. "Smolenskii naryv". Smolensk.

Komissiia TsK VKP(b). 1945. Istoriia vsesoiuznoi kommunisticheskoi partii (bol'shevikov). Kratkii kurs. Moscow.

Kotkin, S. 1995. Magnetic mountain. Stalinism as a civilization. Berkeley: University of California Press.

Kuchkin, A. 1962. Sovetizatsiia Kazachskogo aula 1926-1929 gg. Moscow.

Kukushkin, I. 1968. Sel'skie sovety i klassovaia bor'ba v derevne (19211932 gg.). Moscow.

Leng, H. O. 1973. Die allgemeine Wahl im bolschewistischen Staat. Meisenheim: Hain.

Luhmann, N. 1996. Soziale Systeme. Grundriss einer allgemeinen Theorie. Frankfurt am Main: Suhrkamp.

Maier, R. 1990. Die Stachanov-Bewegung 1935-38. Der Stachanovismus als tragendes und verschärfendes Moment der sowjetischen Gesellschaft. Stuttgart.

Makarov, E., et al. 2000. Piterskie rabochie i "diktatura proletariata". Oktiabr' 1917-1929. Sbornik dokumentov. St. Petersburg.

Manning, R. 1993. The Great Purges in a rural district. Belyi raion revisited. In Stalinist Terror. New Perspectives, edited by J. Getty. Cambridge: Cambridge University Press.

Markevich, A., and A. Sokolov. 2005. "Magnitka bliz sadovogo kol'tsa". Stimuly k rabote na Moskovskom zavode "Serp i molot" 1883-2001 gg. Moscow.

Martin, T. 2001. The Affirmative Action Empire. Nations and Nationalism in the Soviet Union, 1923-1939. Ithaca: Cornell University Press. McLoughlin, B. 2002. Die Massenoperationen des NKWD. Dynamik des 
Terrors 1937/38. In Stalinscher Terror 1939-1941. Eine Forschungsbilanz, edited by V. Hedeler. Berlin: Basis Druck.

Mote, M. 1965. Soviet Local and Public Elections. A Description of the 1963 Elections in Leningrad based on Official Documents, Press Accounts, and Private Interviews. Stanford: Hoover Institution.

Müller, R., editor. 1991. Die Säuberung. Moscow 1936. Stenogramm einer geschlossenen Parteiversammlung. Reinbek: Rowohlt.

Neutatz, D. 2001. Die Moskauer Metro. Von den ersten Plïen bis zur Grossbaustelle des Stalinismus. Cologne: Böhlau.

Petrone, K. 1994. Life has become more joyous, comrades. Politics and Culture in Soviet Celebrations 1934-1939. Ann Arbor: Indiana University Press.

Rees, E., ed. 2002. Centre-Local Relations in the Stalinist State. 1928-1941. Basingstoke: Palgrave.

Rimmel, L. 2000. A Microcosm of Terror, or Class Warfare in Leningrad. The March 1935 Exile of “Alien Elements". In Jahrbücher für Geschichte Osteuropas 48: 528-551.

Rittersporn, G. 1991. Stalinist Simplifications and Soviet Complications. Social Tensions and Political Conflicts in the USSR 1933-1953. Chur: Routledge.

Rolf, M. 2006. Das sowjetische Massenfest. Hamburg: Hamburger Edition.

Rolf, M. 2007. Norm, Abweichung und Aneignung. Kulturelle Konventionen und unkonventionelle Kulturen in der Nachkriegssowjetunion. In Totalitarismus und Demokratie 4: 225-242.

Rosenfeldt, N. 1990. Stalinism as a system of communication. In Essays on Revolutionary culture and Stalinism, edited by J. Strong. Columbus: Slavica Publishers.

Rutschky, K. (editor). 1997. Schwarze Pädagogik. Quellen zur Naturgeschichte der bürgerlichen Erziehung. Berlin: Ullstein.

Ryklin, M. 2003. Räume des Jubels. Totalitarismus und Differenz. Frankfurt am Main: Suhrkamp.

Schaginjan, M. 1952. Das Wasserkraftwerk. Berlin.

Schattenberg, S. 2002. Stalins Ingenieure. Lebenswelten zwischen Technik und Terror in den 1930er Jahren. Munich: Oldenbourg.

Schlögl, R. 2004. Der frühneuzeitliche Hof als Kommunikationsraum. Interaktionstheoretische Perspektiven der Forschung. In Geschichte und Systemtheorie. Exemplarische Fallstudien, edited by F. Becker. Frankfurt am Main: Campus.

Schlögl, R. 2008a. Kommunikation und Vergesellschaftung unter An- 
wesenden. Formen des Sozialen und ihre Transformation in der Frühen Neuzeit. In Geschichte und Gesellschaft 24: 155-224.

Schlögl, R. 2008b. Politik beobachten. Öffentlichkeit und Medien in der Frühen Neuzeit. In Zeitschrift für Historische Forschung 35 (4): 581-616.

Schmitt, C. [1932] 1987. Der Begriff des Politischen. Text von 1932 mit einem Vorwort und drei Corollarien. Berlin: Duncker \& Humblot.

Schröder, H.-H. 1988. Industrialisierung und Parteibürokratie in der Sowjetunion. Berlin: Harrassowitz.

Smith, S. 1985. Red Petrograd. Revolution in the Factories 1917-1918. Cambridge: Cambridge University Press.

Solzhenitsyn, A. 1974. Zhit' ne po lzhi!, http://www.solzhenitsyn.ru/ proizvedeniya/publizistika/stati_i_rechi/v_sovetskom_soyuze/jzit_ ne_po_ljzi.pdf.

Stalin, I. 1976. Werke. Volumes 1-15. Dortmund.

Studer, B. and B. Unfried. 2001. Der stalinistische Parteikader. Identitätsstiftende Praktiken und Diskurse in der Sowjetunion der dreißiger Jahre. Cologne: Böhlau.

Thurston, R. 1996. Life and Terror in Stalin's Russia 1934-41. New Haven: Yale University Press.

Tikhonov, V. 1998. Lishenie izbiratel'nykh prav v Moskve v 1920-1930-e gody. Novye arkhivnye materialy i metody obrabotki. Moscow.

Ul'ianova, S. 2001. Massovye khoziaistvenno-politicheskie kampanii v sisteme stimulirovaniia truda v 1920-e gg. (Kampaniia po podniatiiu proizvoditel'nosti truda v leningradskoi promyshlennosti v 1924-1925 gg.). In Sotsial'naia istoriia. Ezhegodnik: 142-157.

Unfried, B. 1994. Rituale von Konfession und Selbstkritik. Bilder vom stalinistischen Kader. In Jahrbuch für Historische Kommunismusforschung 2: 148-164.

Unfried, B. 2006. "Ich bekenne". Katholische Beichte und sowjetische Selbstkritik. Frankfurt am Main: Campus.

Vatlin, A. 2003. Tatort Kunzewo. Opfer und Täter des Stalinschen Terrors 1937/38. Berlin: Basis Druck.

Weber, M. 1984. Soziologische Grundbegriffe. Tübingen: Mohr.

Wood, E. 2005. Performing Justice. Agitation Trials in Early Soviet Russia. Ithaca: Cornell University Press .

Zaitzeff, L. 1925. Wahlrecht und Wahlpraxis in Sowjetrussland. In Osteuropa 1: 383-392.

Zlatopol'skii, D. 1982. Verkhovnyi Sovet SSSR_vyrazitel' voli sovetskogo naroda. K60-letiiu obrazovaniia SSSR. Moscow. 
